\title{
Adaptasi Budaya Cangkruk'an sebagai Teknik Dalam Panduan Pelatihan Konseling Sebaya
}

\author{
Muhammad Fuadi ${ }^{1}$, Blasius Boli Lasan ${ }^{1}$, Arbin Janu Setiyowati ${ }^{1}$ \\ ${ }^{1}$ Bimbingan dan Konseling-Universitas Negeri Malang
}

\begin{tabular}{l}
\hline \hline INFO ARTIKEL \\
\hline Riwayat Artikel: \\
Diterima: $13-03-2020$ \\
Disetujui: $25-08-2020$ \\
\hline
\end{tabular}

\section{Kata kunci:}

cangkruk'an culture: peer counseling; prosocial; budaya cangkruk'an; konseling sebaya; prososial

\begin{abstract}
ABSTRAK
Abstract: The purpose of this research and development is to produce a culture based Cangkruk'an peer counseling training manual that can be used by peer counselors at school. Research and development uses the Borg and Gall 10 model and has been adjusted to the needs of researchers to 7 and uses quantitative analysis of the agreement of experts from the Grinelle model. First, preliminary studies, planning, making initial products in the form of manuals for peer counselors, validation expert tests, namely learning media experts, get an assessment percentage of $81 \%$ (very high) in terms of graphics, product content, and language. Second, two experts test Guidance and Counseling with an average percentage score of $73 \%$ (high) in terms of accuracy of usefulness and feasibility. Third, the validation of the cangkruk'an cultural experts got an average score of $92 \%$ (very high) in terms of accuracy and clarity. Fourth, the validation of the guidance and counsling Material expert is by five Counselor's getting an average score of $64 \%$ accuracy (moderate). It can be concluded that all the results of the assessment from the validator of this guide product are in the Good category so they are suitable for use and continue to the next stage.
\end{abstract}

\begin{abstract}
Abstrak: Tujuan dari penelitian dan pengembangan ini adalah menghasilkan buku panduan pelatihan konseling sebaya berbasis budaya cangkruk'an yang nantinya dapat digunakan konselor sebaya di sekolah. Penelitian pengembangan ini menggunakan model Borg and Gall 10 tahap dan telah disesuaikan dengan kebutuhan peneliti menjadi tujuh tahap dan menggunakan analisis data verbal dan numerik tentang kesepakatan para ahli dari model Grinelle. Pertama, studi pendahuluan, perencanaan, pembuatan produk awal berupa buku panduan untuk konselor sebaya, uji ahli validasi yaitu ahli media pembelajaran mendapatkan persentase penilaian sebesar $81 \%$ (sangat tinggi) ditinjau dari segi kegrafisan, konten produk, dan kebahasaan. Kedua, dua orang uji ahli Bimbingan dan Konseling dengan skor persentase rata-rata $73 \%$ (tinggi) ditinjau dari ketepatan kegunaan dan kelayakan. Ketiga, validasi dari ahli budaya cangkruk'an mendapat skor rata-rata 92\% (sangat tinggi) ditinjau dari ketepatan dan kejelasan. Keempat, validasi ahli materi BK yaitu oleh lima orang guru BK mendapatkan skor rata-rata ketepatan 64\% (sedang). Dapat disimpulkan bahwa semua hasil penilaian dari validator produk panduan ini masuk pada kategori Baik sehingga layak digunakan dan dilanjutkan ke tahap berikutnya.
\end{abstract}

\author{
Alamat Korespondensi: \\ Muhammad Fuadi \\ Bimbingan dan Konseling \\ Universitas Negeri Malang \\ Jalan Semarang 5 Malang \\ E-mail: fuadimuhammad252@gmail.com
}

Remaja memiliki tugas perkembangan yang berhubungan dengan penyesuaian sosial, salah satunya ialah penyesuaian diri dengan meningkatkan pengaruh kelompok sebaya, perubahan dalam perilaku sosial, pengelompokkan sosial yang baru dalam seleksi persahabatan, nilai-nilai baru dalam dukungan, serta penolakan sosial (Hurlock dalam Bingah, 2015). Contoh lain dari perilaku prososial, seperti membantu dan bekerjasama merupakan dasar pembentukan perilaku positif untuk menjalin hubungan baik dengan individu lainnya. Menurut Turner, Crisp, \& Lambert (2007) perilaku prososial (prosocial behavior) diklasifikasikan, seperti persahabatan (friendship), kedermawanan, pengorbanan, saling berbagi, perilaku menolong (helping behaviour), dan perilaku kooperatif (cooperative attitude).

Pada era revolusi 4.0 dengan semakin berkembangnya tekonologi manusia semakin dimudahkan dengan segala urusannya dengan gadget, hampir seluruh aktivitas manusia dalam era moderenisasi tidak lepas dari bantuan smartphone dan akses internet yang cepat, semua itu demi memudahkan segala aktivitas dan efisiensi waktu mereka dalam beraktivitas. Namun, kondisi tersebut berdampak negatif dari penggunaan gadget yang tidak terkontrol membuat manusia lupa sebagai makhluk sosial yang butuh dengan manusia lainnya dalam bentuk sikap prososial atau saling tolong menolong, terlebih di negara Indonesia 
dengan latar belakang budaya bagian timur yang terkenal dengan semangat gotong-royongnya sejak dahulu. Seiring berjalannya waktu, perilaku prososial tersebut perlahan mulai terkikis dalam kehidupan sehari-hari dengan semakin bergantungnya hidup manusia dengan teknologi, khususnya para siswa di sekolah, banyak sekali perilaku siswa yang semakin tak acuh dengan sebayanya.

Perkembangan individu akan terbantu apabila anak memiliki teman yang secara sosial terampil dan bersifat suportif., sedangkan teman-teman yang suka memaksakan kehendak dan banyak menimbulkan konflik akan menghambat perkembangan. Memperhatikan pentingnya peran sebaya, pengembangan lingkungan sebaya yang positif merupakan cara efektif yang dapat ditempuh untuk mendukung perkembangan remaja. Dalam kaitannya dengan keuntungan remaja memiliki kelompok sebaya yang positif (Laursen, 2005) menyatakan bahwa kelompok sebaya yang positif memungkinkan remaja merasa diterima, memungkinkan remaja melakukan katarsis, serta memungkinkan remaja menguji nilai-nilai baru dan pandangan-pandangan baru. Lebih lanjut, Laursen menegaskan bahwa kelompok sebaya yang positif memberikan kesempatan kepada remaja untuk membantu orang lain dan mendorong remaja untuk mengembangkan jaringan kerja untuk saling memberikan dorongan positif. Interaksi diantara sebaya dapat digunakan untuk membentuk makna dan persepsi serta solusi-solusi baru. Budaya sebaya yang positif memberikan kesempatan kepada remaja untuk menguji keefektifan komunikasi, tingkah laku, persepsi, dan nilai-nilai yang mereka miliki. Budaya sebaya yang positif sangat membantu remaja untuk memahami bahwa dia tidak sendirian dalam menghadapi berbagai tantangan. Budaya sebaya yang positif dapat digunakan untuk membantu mengubah tingkah laku dan nilai-nilai remaja (Laursen, 2005).

Salah satu upaya yang dapat dilakukan untuk membangun budaya sebaya yang positif adalah dengan mengembangkan konseling sebaya dalam komunitas remaja di sekolah melalui kegiatan cangkruk'an. Anak dan remaja, terlebih siswa SMK yang sebagian besar pernah mengalami permasalahan pribadi, Pada dasarnya peer counseling sudah sering terjadi dalam kehidupan sehari-hari. Misalnya seorang individu yang menceritakan masalah yang dialami kepada rekan kerja ataupun teman di sekolah tanpa disadari individu tersebut sedang melakukan proses konseling, karena biasanya salah satu dari individu tersebut ada yang bertindak layaknya seperti seorang konselor. Seperti yang dikemukakan oleh (Suwarjo dalam Prasetiawan, 2015) bahwa, "selama proses curhat, ngerumpi atau sekadar omong-omong menghilangkan bete (bosan) tanpa disadari salah satu (kadang juga lebih dari satu) diantara mereka bertindak layaknya seorang pembimbing sedangkan lainnya sebagai konselinya". Tindall dan Gray (dalam Muslikah, Hariyadi, \& Amin, 2016) juga mendefinisikan konseling sebaya sebagai suatu ragam tingkah laku membantu secara interpersonal yang dilakukan oleh individu non-profesional yang berusaha membantu orang lain. Menurut Tindall \& Gray, konseling sebaya mencakup hubungan membantu yang dilakukan secara individual (one-to-one helping relationship), kepemimpinan kelompok, kepemimpinan diskusi, pemberian turorial, dan semua aktivitas interpersonal manusia untuk membantu atau menolong. Penelitian Osodo (dalam Febrianti \& Mulawarman, 2019) menunjukkan bahwa konseling sebaya memiliki peran penting dalam mempromosikan disiplin diantara siswa di SLTA khususnya SMK. Penelitian ini merekomendasikan bahwa konselor sebaya harus termotivasi untuk tampil maksimal.

Cangkruk'an dalam arti konvensional, yakni cangkruk, jagongan, atau kongkow di depan rumah atau di tepi jalan kampung dengan para tetangga. Setiap individu di dalam aktivitas cangkrukan merupakan makhluk bebas yang boleh berbicara dan berekspresi apa saja, sepanjang tidak ada yang dirugikan oleh apa yang dilakukannya. Tidak heran jika di warung kopi disaksikan berbagai sumpah serapah seringkali muncul dan hadir dalam setiap pembicaraan satu sama lain. Benarlah jika kemudian disebut bahwa cangkruk'an di warung kopi menjadi aktivitas yang "menelanjangi" diri sendiri dari semua bentuk pencitraan. Ketika di warung kopi, semua identitas yang melekat dalam citra selama ini bisa menjadi cair karena kesetaraan satu sama lain. Itulah sebabnya, warung kopi menjadi suatu penanda mencairnya formalitas. Satu sama lain saling mengidentifikasi diri dengan kesetaraannya. Citra yang dihadirkan sama, bahasa yang digunakan tidak berbeda, termasuk dalam soal selera makanan (Santoso, 2017).

Hadirnya program konseling sebaya di sekolah ini diharapkan membantu kinerja konselor/guru BK agar mempermudah dalam menangani permasalahan siswa. Selain itu, media cangkruk'an dianggap sangat tepat sebagai media dalam setiap sesi pertemuan konseling, selain berbahasa daerah khas Jawa Timur, cangkruk'an juga menjadi sebuah aktivitas gaya hidup baru remaja millenial sekarang.

\section{METODE}

Jenis penelitian yang digunakan disini adalah penelitian dan pengembangan (Research and development), yaitu metode penelitian yang digunakan untuk menghasilkan produk tertentu, lalu menguji efektifnya produk tersebut (Sugiyono dalam Kusnadi, 2016). Metode penelitian dan pengembangan menggunakan model Borg dan Gall. Prosedur penelitian dan pengembangan Borg dan Gall (1983) dalam penelitian ini sudah disesuaikan dengan apa yang peneliti butuhkan. Untuk tahapan prosedur penelitian dan pengembangan produk ini diawali dengan (1) studi pendahuluan, (2) perencanaan, (3) pengembangan produk awal, (4) validasi ahli, (5) revisi produk awal, (6) uji coba pengguna, dan (7) revisi produk. Penelitian dan pengembangan ini telah diuji ahli atau divalidasi oleh beberapa ahli sebagaimana ditunjukkan pada tabel 1. 
Tabel 1. Validator Ahli

\begin{tabular}{clc}
\hline No & \multicolumn{1}{c}{ Validator ahli } & Jumlah \\
\hline 1 & Ahli Bimbingan dan Konseling & 2 \\
2 & Ahli media pembelajaran & 1 \\
3 & Ahli budaya cangkruk'an & 1 \\
4 & Ahli materi Bimbingan dan konseling & 5 \\
\hline
\end{tabular}

Untuk uji pengguna produk dilakukan kepada delapan orang siswa yang suka rela mengikuti kegiatan pelatihan konseling sebaya di sekolah mulai awal sampai dengan akhir.

\section{Analisis Data}

Analisis data kuantitatif hasil penilaian dan evaluasi yang diperoleh dari instrumen uji ahli bimbingan dan konseling, ahli media pembelajaran, ahli budaya cangkruk'an, dan ahli materi BK akan dianalisis dengan menggunakan analisis Data Kuantitatif dan kemudian dianalisis menggunakan derajat kesepakatan Grinnel dalam (Sukarno \& Handarini, 2017). Hal ini akan diperuntukan untuk menghitung presentase kesepakatan antar subjek untuk mengungkapkan reliabilitas kesepakatan untuk setiap butir penilaian terhadap tingkat keberterimaan produk dengan rumus:

$$
\text { Percentage of Agreement }=\frac{\text { Aggrements }}{\text { Disagreements }+ \text { agreements }} \times 100 \%
$$

\section{Keterangan: \\ Agreemets : Jumlah subjek yang sepakat \\ Disagreements : Jumlah subjek yang tidak sepakat}

Data persentase kesepakatan terhadap setiap butir penilaian produk diinterpretasikan dengan kriteria, sebagai berikut.

Tabel 2. Persentase Kesepakatan

\begin{tabular}{cl}
\hline Interval Presentasi & Kategori Kesepakatan \\
\hline $81-100 \%$ & Sangat Tinggi \\
$61-80 \%$ & Tinggi \\
$41-60 \%$ & Sedang \\
$21-40 \%$ & Kurang \\
$0-20 \%$ & Sangat kurang \\
\hline
\end{tabular}

\section{HASIL}

Tujuan pengembangan panduan pelatihan konseling sebaya berbasis budaya cangkruk'an untuk mengembangkan perilaku prososial siswa SMK adalah berupa Buku panduan yang dikembangkan ini terdiri dari (1) sampul depan panduan menggambarkan sekelompok orang yang sedang melakukan kegiatan cangkruk'an (2) kata pengantar, berisi ucapan terimakasih kepada pihak yang telah membantu dalam pengembangan produk, (3) bagian I terdiri dari Rasional, urgensi, visi dan misi, manfaat dan tujuan pelatihan (4) bagian II sasaran pelatihan, kualifikasi peserta pelatihan, prosedur dan petunjuk pelaksanaan, tahapan pelaksaan (5) bagian III, menjelaskan tentang isi materi di setiap pertemuan yaitu pembentukan kelompok, orientasi pengenalan konseling sebaya, melatih keterampilan mendengar memahami dan merespon, keterampilan dasar konseling, simulasi dan evaluasi, (6) bagian IV, berisi simpulan dan saran, dan (7) daftar pustaka.

Pengujian yang dilakukan oleh ahli dan calon pengguna diajadikan sebagai acuan untuk mengetahui akseptabilitas keetepatan kegunaan dan kelayakan produk pengembangan panduan. Hasil pengujian ahli selanjutnya dihitung dengan menggunakan menggunakan derajat kesepakatan Grinell dengan hasil sebagai berikut.

\section{Data Hasil Uji Ahli Media Pembelajaran}

Uji ahli media pembelajaran dilakukan oleh ahli dengan kualifikasi dosen minimal S3 teknologi pembelajaran dengan minimal pengalaman selama 10 tahun, berikut hasil dari uji ahli media pembelajaran. 
Tabel 3. Data Hasil Uji Ahli Media Pembelajaran

\begin{tabular}{clcl}
\hline No & Indikator & Skor rata-rata & Kategori \\
\hline 1 & Kegrafisan & $71 \%$ & Tinggi \\
2 & Konten produk & $80 \%$ & Tinggi \\
3 & Kebahasaan & $92 \%$ & Sangat tinggi \\
\hline
\end{tabular}

Dari data diatas memperoleh rata-rata skor tinggi dan sangat tinggi dari ahli media pembelajaran yaitu mengenai aspek kegrafisan, konten produk, dan kebahasaan yang mana rata-rata keseluruhan yaitu sebesar $81 \%$ yaitu sangat tinggi. Selanjutnya ahli media pembelajaran memberikan kritik dan saran sebagai berikut. Ahli media pembelajaran juga memberikan kritik dan saran untuk panduan ini diantaranya Sumber (copyright) setiap gambar harus disampaikan dibawah gambar karena setiap gambar ataupun tulisan yang kita kutip mengandung hak cipta karya milik orang lain harus kita hargai bersama sesuai dengan (UU No. 28 Tahun 2014) tentang hak cipta karya tulis. Kedua yaitu gradasi warna disesuaikan, font huruf diperkecil menyesuaikan ukuran kertas dan perlunya tambahan tentang Riwayat penulis.

\section{Uji Ahli Bimbingan dan Konseling}

Uji ahli Bimbingan dan Konseling dilakukan kepada dosen S3 Bimbingan dan Konseling dengan minimal pengalaman selama 10 tahun. Adapun hasilnya ditunjukkan pada tabel 4.

\section{Tabel 4. Data Hasil Uji Ahli Bimbingan dan Konseling}

\begin{tabular}{cccl}
\hline No & Aspek & Skor rata-rata & \multicolumn{1}{c}{ Kategori } \\
\hline 1 & Ketepatan & $70 \%$ & Tinggi \\
2 & Kegunaan & $68 \%$ & Tinggi \\
3 & Kelayakan & $83 \%$ & Sangat tinggi \\
\hline
\end{tabular}

Berdasarkan data dari kedua ahli Bimbingan dan Konseling mengenai aspek ketepatan kegunaan dan kelayakan memproleh rata-rata keseluruhan sebesar 74\%. Selanjutnya, ahli media pembelajaran memberikan kritik dan saran (1) ahli BK pertama menyarankan panduan ini dipergunakan oelh konselor profesional yang melatihkan kepada siswa, (2) tujuan umum hendaknya berisi kemauan tujuan yang kana dicapai peserta pelatihan, (3) penyempurnaan tujuan khusus yang akan dicapai pada materi setiap pertemuan. Untuk ahli BK hanya memberikan masukan mengenai header dan footer pada buku panduan agar lebih ditata ulang agar menarik. Beberapa masukan tersebut menjadi bahan pertimbangan bagi peneliti untuk penyempurnaan produk panduan.

\section{Uji Ahli Budaya Cangkruk'an}

Pada uji ahli Budaya Cangkruk'an dilakukan oleh ahli budayawan asli Jawa Timur yaitu bapak Kartolo yang sudah menghasilkan karya dan pengalamannya sebagai ketua paguyuban seni Ludruk Jawa timuran yang terkenal di era 80 — 90 an. Untuk aspek penilaian, meliputi aspek ketepatan tentang penulisan gagasan, kesesuaian penggunaan bahasa, dan ketepatan teknik cangkruk'an. Selain itu, tentang kejelasan mengenai nilai egaliter budaya jawa timuran dan nilai kesopanan berbahasa Adapun hasilnya ditunjukkan pada tabel 5.

Tabel 5. Data Hasil Uji Ahli Budaya Cangkruk'an

\begin{tabular}{cccc}
\hline No & Indikator & Skor rata-rata & Kategori \\
\hline 1 & Ketepatan & $90 \%$ & Sangat tinggi \\
2 & Kejelasan & $94 \%$ & Sangat tinggi \\
\hline
\end{tabular}

Hasil uji ahli budaya cangkruk'an sangat memuaskan dimana memperoleh rata-rata keseluruhan sebesar $92 \%$ yang termasuk kategori sangat tinggi. Selain itu, hasil tersebut juga mendapat kritik dan saran dari ahli budaya cangkruk'an mengenai penggunakan cangkruk'an yang diadaptasi menjadi teknik dalam konseling sebaya ini. Terutama mengenai penguunaan bahasa cangkruk'an adalah Jawa Timur Suroboyoan yang cenderung lebih sarkastik. Meskipun pada kenyataan dilapangan bahasa tersebut tidak menjadi kendala ketika dipergunakan untuk berbicara kepada teman sebaya namun mengingat buku panduan ini nantinya dipergunakan pada ranah pendidikan, ahli budaya menyarankan untuk mengurangi penggunaan kata “cuk” karena dianggap terlalu kasar dan kurang pantas.

Uji Ahli Materi Bimbingan Dan Konseling

Uji ahli materi Bimbingan dan konseling dilakukan kepada lima konselor sekolah khususnya berlatar belakang asli Jawa Timur dan mengetahui secara singkat tentang dinamika cangkruk'an yang sedang berada di lingkungannya. 
Tabel 6. Hasil Uji Ahli Materi Bimbingan dan Konseling

\begin{tabular}{clcc}
\hline No & Indikator & Skor rata-rata & Kategori \\
\hline 1 & Ketepatan & $60 \%$ & Sedang \\
2 & Kegunaan & $67 \%$ & Tinggi \\
3 & Kelayakan & $60 \%$ & Sedang \\
\hline
\end{tabular}

Dari kelima konselor di sekolah yang ditunjuk sebagai ahli materi Bimbingan konseling dengan harapan buku panduan pelatihan ini sudah disesuaikan oleh calon pengguna yaitu siswa calon konselor sebaya dengan harapan dapat digunakan secara layak. Data diatasa memperoleh skor rata-rata keseluruhan sebesar $62 \%$ yaitu tinggi dan layak digunakan. Berikut kritik dan saran dari ahli bimbingan dan konseling. Pertama konselor WI yang menyarankan perbaikan kalimat pada setiap penulisan perlu diperhatikan agar pembaca lebih mudah memahami. Kedua konselor IE memberikan masukan tentang ukonsistensi penggunaan istilah konselor sebaya dan calon konselor sebaya dan tempat yang digunakan dalam melaksanakan kegiatan pelatihan. Ketiga konselor ND menyarankan untuk didalam buku panduan disediakan RPP singkat, penggunaan teknik cangkruk'an dianggap masih biar gender karena dianggap lebih cocok untuk pria saja. Konselor AA lebih penyesuaian penggunaan istilah pada subjek peneliti lebih di teliti lagi, relevansi waktu yang dianggap terlalu lama, dan menyaraankan untuk membentuk tim editor agar kesalahan penulisan atau typo lebih diminimalisir. Terakhir konselor TM mengapresiasi dari segi tampilan cover dan isi buku yang menurutnya sangat baik dan Semoga cangrkuk'an dapat diadaptasi menjadi tehnik atau media dalam bidang bimbingan dan konseling di sekolah.

Tahap selanjutnya produk panduan ini dilatihkan oleh peneliti kepada delapan siswa yang akan dilatih sebagai konselor sebaya di sekolah. Antusiasme dari siswa sangat tinggi karena yang mereka ketahui selama ini tentang konseling hanya sekedar di ruangan yang terkadang membuat siswa masih enggan dan segan untuk mengungkapkan masalahnya kepada guru BK. Hadirnya konseling sebaya ini membuat konselor sebaya mengetahui dan bisa belajar tentang masalah yang dihadapi teman sebayanya. terbukti dari hasil evaluasi yang dilakukan peneliti, konselor sebaya sudah dapat melaksanakan konseling di tempat manapun yang mereka sukai sembari dengan menyeruput kopi dan makanan ringan. Namun beberapa konselor sebaya juga mengeluhkan bahwa ada beberapa klien atau konseli mereka terlalu banyak berbelit tentang masalah pribadinya, sebagian konselor sebaya juga merasa kesulitan ketika mendapatkan klien anak introvert. Maka dari itu perlunya pendampingan dari guru BK di sekolah agar nantinya program konseling sebaya ini berjalan lebih optimal di setiap sekolah sehingga dapat membantu kinerja guru BK di sekolah tentang masalah siswa.

\section{PEMBAHASAN}

Gagasan dan ide penelitian pengembangan ini berawal dari gaya hidup remaja milenial zaman sekarang yang bergaya hidup dengan suka nongkrong di kafe atau warung kopi. Dalam masyarakat Jawa timur disebut dengan istilah cangkruk'an. Dalam sebuah cangkruk'an tentunya setiap orang bebas berekspresi tanpa adanya aturan formal yang mengikat. Namun, seiring dengan berkembangnya zaman, rasa kepekaan terhadap teman semakin lama semakin memudar dengan dimanjakannya manusia dari berkembangnya dunia teknologi dan informasi. Akan tetapi, melihat kenyataan di lapangan, warung atau kafe kini semakin banyak digemari oleh semua kalangan sebagai tempat untuk bercengkrama, tempat untuk saling berbagi antar sesama, dan sebagai tempat untuk saling bertukar pikiran dalam dunia bisnis ataupun yang lain. Disisi lain, kepekaan dan rasa peduli remaja terhadap teman sebayanya juga mulai memudar, beberapa kalangan remaja yang gemar cangkruk'an kini tak lagi sebagai tempat untuk mengobrol satu sama lain, namun mereka hanya memanfaatkan akses Wi-fi yang tersedia untuk bermain game sehingga mereka hanya sibuk dengan gadgetnya masing-masing tanpa adanya obrolnya yang bermanfaat.

Perilaku prososial dapat ditingkatkan dan dikembangkan khususnya melalui pendekatan bimbingan dan konseling pada ranah pendidikan. Penelitian Megawati \& Herdiyanto (2016) terdapat adanya hubungan positif antara perilaku prososial dengan psikological well-being (Bingah, 2015) perilaku prososial dapat ditingkatkan melalui teknik sosiodrama. Kurniawati Husada (2013) juga menjelaskan tentang konsep diri dan kecenderungan perilaku prososial pada kejadian kecelakaan di jalan raya menghasilkan bahwa adanya pengaruh positif konsep diri maka semakin tinggi kecenderungan perilaku prososial atas kecelakaan di jalan raya pada mahasiswa Umsida. Sebaliknya semakin negatif konsep diri maka semakin rendah kecenderungan perilaku prososial atas kecelakaan di jalan raya pada mahasiswa Universitas Muhammadiyah Sidoarjo.

Sementara penelitian terdahulu mengenai konseling sebaya diantaranya Pandang dalam (Sari, 2017) mengenai pengembangan model program konseling sebaya sebagai media praktikum konseling, dalam hal ini beliau memberikan pelatihan kepada mahasiswa proram praktik lapangan yang digunakan dalam konseling sebaya kepada siswa sehingga para mahasiswa dapat mengonseling siswa layaknya seperti teman sebaya sendiri. Kemudian Suwarjo (2008) beliau juga mengembangkan model konseling sebaya yang digunakan didalam panti asuhan untuk mengembangkan daya lentur atau resiliensi antar teman sebaya pada panti asuhan tersebut sehingga mereka dapat saling terbuka satu sama lain didalam panti asuhan. Pada penelitian lain tentang efektifitas teman sebaya ini diantaranya oleh (Uke, Ramli, \& Triyono, 2017) yang meneliti tentang teman sebaya dapat mengurangi prokastinasi akademik khususnya pada siswa SMK. Pada beberapa penelitian ini tidak ada pendekatan yang berbasis budaya daerah, maka peneliti tertarik dengan memperbaharui dan mengembangan panduan konseling sebaya menggunakan teknik berbasis budaya. Hal ini selaras dengan yang dikemukakan oleh (UNESCO, 2001) menyatakan bahwa media yang tepat dalam mengajarkan karakter bersosial pada siswa haruslah bermuatan budaya didalamnya. Sependapat dengan Rahmi, Mappiare-AT, \& 
Muslihati (2017) yang menyatakan bahwa konseling adalah bagian dari perjumpaan antar budaya yaitu budaya subjektif tentang sistem nilai kearifan lokal dan tata kebiasaan yang terkandung pada isi penyelenggaraan konseling.

Pada tahap studi pengembangan dilaksanakan dengan melakukan studi literatur dan studi lapangan berdasarkan obervasi berupa pengamatan langsung dan wawancara. Berdasarkan studi literatur, semakin berkembangnya kebutuhan sosial remaja maka semakin beragam permasalahan yang terjadi. Remaja sebagai makhluk sosial lebih senang bercerita tentang masalahnya kepada sehabat yang seusianya, merujuk pada pendapat Santrock (dalam Auliatunida, Pramono, \& Dewi, 2011) yang menjelaskan bahwa kedekatan seorang pada masa remaja cenderung meningkat daripada kepada orangtua. Pertimbangan lain tentang perlunya pengembangan buku panduan konseling sebaya yaitu tentang ketersediaanya guru BK khususnya SMK di kota yang kurang memenuhi rasio yaitu 1:150 ( Permendikbud no. 111, 2014) beberapa guru BK di kota Pasuruan yang pada dasarnya mengeluhkan tentang rumitnya tuntutan pelaksaan administrasi program BK di sekolah. Kewajiban tersebut dianggap sangat menyita waktu dan memakan beban kerja yang berat dikarenakan tuntutan kurikulum dan stakeholder sekolah mengharuskan adanya pelaporan tertulis dari setiap perkembangan siswa mengenai aspek pribadi sosial berbasis IT, dimana notabene guru BK di beberapa SMK di kota Pasuruan masih kurang memahami tentang teknologi berbasis komputerisasi. Fakta lain yaitu kurangnya pengenalan tentang konseling di lingkungan sekolah dirasa sangat minim sehingga perubahan anggapan peran guru BK yang menjadi polisi sekolah sangat masih terasa di beberapa sekolah khususnya SMK di kota Pasuruan. Selama ini pengenalan tentang konseling remaja justru dari instansi non pendidikan seperti BKKBN, PMR, dan P2TP2A (pusat pengaduan pelayanan terpadu perberdayaan perempuan dan anak). Disisi lain, perlunya pengenalan tentang konseling sebaya dirasa sangat penting bagi peneliti untuk sebagai langkah penyembuhan awal kepada siswa yang bermasalah sebelum melakukan konseling kepada konselor profesional.

Selanjutnya pada tahap perencanaan produk dilakukan untuk merancang produk berupa buku panduan pelatihan konseling sebaya berbasis budaya cangkruk'an. Tahapan ini dilakukan rancangan produk awal berupa buku panduan untuk calon konselor sebaya pada tingkat SMK dengan di sesuaikan dengan budaya khas jawa timur cangkruk'an. buku panduan ini berisi tentang sajian umum mengenai tentang pengenalan konseling sebaya, keterampilan dasar konseling yang berciri khas budaya jawa timur, dan percakapan simulasi konseling individu dan kelompok yang berbahasa jawa timur.

Setelah tahap perencanaan dan sudah menghasilkan prototype, produk buku panduan selanjutnya divalidasi oleh beberapa hali diantaranya ahli bimbingan dan konseling, media pembelajaran, ahli budaya, dan ahli materi Bimbingan dan konseling. Untuk yang pertama dari ahli media pembelajaran yaitu dilakukan oleh ahli dengan kualifikasi dosen minimal S3 teknologi pembelajaran dengan minimal pengalaman selama 10 tahun, berikut hasil dari uji ahli media pembelajaran

dengan memperoleh rata-rata skor tinggi dan sangat tinggi dari ahli media pembelajaran yaitu mengenai aspek kegrafisan, konten produk dan kebahasaan yang mana rata-rata keseluruhan yaitu sebesar $81 \%$ yaitu sangat tinggi. Pada Uji ahli Bimbingan dan Konseling dilakukan oleh ahli sebanyak dua orang dengan kualifikasi dosen minimal S3 Bimbingan dan Konseling dengan minimal pengalaman selama 10 tahun memperoleh rata-rata skor tinggi dan sangat tinggi dari kedua ahli Bimbingan yaitu mengenai aspek ketepatan kegunaan dan kelayakan yang mana rata-rata keseluruhan yaitu sebesar 74\% yaitu tinggi.

Pada Uji ahli Budaya Cangkruk'an dilakukan oleh ahli budayawan asli jawa timur yaitu bapak Kartolo yang sudah menghasilkan karya dan jam terbangnya di ranah nasional dan internasional dan pengalamannya sebagai ketua paguyuban seni Ludruk Jawa timuran yang terkenal di era 80-90an. Cangkruk'an sendiri tidak lepas dari namanya budaya arek yang terletak di sisi timur Kali Brantas, yaitu mulai dari Kediri dan perbatasan dengan Blitar. Kemudian berlanjut hingga Malang, Jombang, Mojokerto, Sidoarjo, Pasuruan, Gresik, dan Surabaya, sedangkan dalam perkembangannya, budaya Arek tidak lepas dari keberadaan dari komunitas remaja di kampong. Terkait dengan komunitas remaja kampung, terdapat tiga konsep simbolik yang digunakan dalam interaksi sosial sehari-hari dan tiga kosep simbolik tersebut dipahami sebagai karakter Arek Suroboyo, yaitu egaliter yang dipahami dengan arti kerakyatan, demokratis yang diartikan dengan keterbukaan, dan solidaritas. Abdillah dalam (Sungkowati, 2019). Konsep-konsep yang dimaksud terwujud dalam interaksi sosial sehari-hari terutama ketika masing-masing warga masyarakat berkumpul atau bertemu dalam berbagai bentuk pertemuan. Pada umumnya pertemuan yang paling menonjol terkait dengan ketiga konsep simbolik tersebut diatas adalah cangkruk'kan (Santoso, 2017).

Penilaian aspek selanjutnya yaitu aspek ketepatan tentang penulisan gagasan, kesesuaian penggunaan bahasa dan ketepatan teknik cangkruk'an yang kedua tentang kejelasan mengenai nilai egaliter budaya jawa timuran dan nilai kesopanan berbahasa dengan memperoleh hasil rata-rata 92\% (sangat tinggi) tetapi perlu lagi penyesuaian yang terdapat pada buku panduan tersebut. Validasi terakhir dari uji ahli materi Bimbingan dan konseling dilakukan kepada lima konselor sekolah khususnya berlatar belakang asli Jawa Timur dan mengetahui secara singkat tentang dinamika cangkruk'an di lingkungannya. Dari kelima konselor di sekolah yang ditunjuk sebagai ahli materi Bimbingan Konseling diharapakan buku panduan pelatihan ini sudah disesuaikan oleh calon pengguna yaitu siswa calon konselor sebaya.

Pada penelitian di luar negeri, konseling sebaya tidak hanya diterapkan di ranah pendidikan (Rozga, Kerver, \& Olson, 2015) konseling sebaya dilakukan oleh sekelompok ibu menyusui guna untuk pola hidup sehat demi kesuburan dan kelancaran ASI. Tikawati (2014) juga menjelaskan konseling sebaya dapat membantu dalam pemilihan karir siswa di Hongkong. Pada penelitian terdahulu (Kusumawati, Astuti, Darnoto, Wijayanti, \& Setiyadi, 2015) konseling sebaya efektif untuk menentukan masalah siswa sehingga siswa dapat lebih teliti dan sadar akan masalah pribadinya sendiri. Zuhara (2015) juga menjelaskan konseling sebaya dapat mereduksi kecanduan game online pada siswa. 
Pada penelitian lain tentang konseling berbasis budaya nusantara sudah diteliti oleh beberapa peneliti sebelumnya seperti penelitian oleh Habsy, Hidayah, Lasan, Muslihati, \& Fudholi (2019) mengenai model konseling semar yang mana kita ketahui bahwa Semar adalah tokoh wayang pada masa majapahit kuno yang terkenal dengan karakter tubuh pendek dan perut buncit, namun memiliki sifat bijaksana dan sakti mandraguna. Hadirnya model konseling ini bertujuan agar terdapat model konseling yang berbasis budaya Indonesia dan dapat dilaksanakan sesuai dengan karakteristik inidividu. Mengenai budaya cangkruk'an juga banyak diteliti oleh peneliti sebelumnya di bidang pendidikan dan sosial, seperti penelitian Santoso, (2017) sebagai teknik diskusi kelompok dengan membandingkan dari teori barat yaitu segitiga Karpman dan hasilnya adanya perbedaan dari segi keluwesan, egaliter, dan keterbukaan diri. Tikawati (2014) menjelalaskan bahwa dengan cangkruk'an orang mengidentifikasi diri secara netral tanpa ada kekhawatiran perlakuan diskriminatif dan ketidakadilan sosial. Arifin, Wibisono, \& Rochiyati (2013) menjelaskan terdapat terdapat nilai kesopanan berbahasa khususnya di Jawa Timur yang mana seolah-olah sombong tapi dermawan, dan seolah-olah mengolok, tetapi demi keakraban.

Dari beberapa hasil penelitian diatas dapat disimpulkan bahwa konseling sebaya jika dipadukan dengan budaya lokal khususnya cangkruk'an diharapkan dapat memberikan warna baru tentang dunia bimbingan dan konseling yang berbasis budaya. Dengan demikian, konseling dapat lebih diterima oleh siswa dan semua stakeholder sekolah supaya nantinya optimalisasi kinerja guru dan pengentasan masalah siswa dapat mudah teratasi oleh hadirnya program konseling sebaya di sekolah.

\section{SIMPULAN}

Produk yang dihasilkan dalam penelitian pengembangan ini berupa buku panduan pelatihan konseling sebaya berbasis budaya cangkruk'an untuk mengembangkan perilaku prososial siswa SMK yang berfungsi sebagai layanan kuratif untuk memfasilitasi siswa yang bermasalah dan bekerjasama dengan konselor profesional sekolah.

Produk yang dihasilkan telah diuji cobakan pada beberapa ahli, seperti ahli media, ahli budaya, dan ahli bimbingan konseling guna mengetahui tingkatan keberterimaan. Tingkat keberterimaan tersebut terdiri atas tiga aspek, yaitu aspek kegunaan, kelayakan, dan ketepatan. Berdasarkan hasil uji coba ahli media, ahli budaya, dan ahli bimbingan konseling menyatakan produk dapat diterima serta layak untuk direalisasikan pada siswa SMK.

Adapun saran yang ditujukan untuk siswa konselor sebaya dan peneliti selanjutnya. Pertama untuk siswa konselor sebaya, dapat menjadi asisten konselor profesional sekolah guna untuk menggali permasalahan yang terjadi pada siswa dan bertanggung jawab atas semua kerahasiaan permasalahan klien. Kedua, untuk peneliti selanjutnya, dapat melanjutkan penelitian pengembangan ini dengan melakukan uji kelompok terbatas, melakukan revisi produk kemudian melakukan penelitian eksperimen guna mengetahui keefektivitasan produk panduan pelatihan konseling sebaya ini.

\section{DAFTAR RUJUKAN}

Arifin, A. S., Wibisono, B., \& Rochiati, E. (2013). Analisis Prinsip Kesopanan Berbahasa Dalam Dialog Antarpelaku pada Video Grammar Suroboyo.

Auliatunida, Z., Pramono, J.S. \& Dewi, A. (2011). Pengaruh Teman Sebaya Terhadap Perilaku Seksual Pada Remaja di SMA N 8 Samarinda. Jurnal Husada Mahakam, III(2), 1-12.

Bingah, Mi. (2015). Upaya Meningkatkan Perilaku Prososial melalui Tekhnik Sosiodrama pada Siswa Kelas VII C SMPN 3 Ngadiro, Kab Pacitan. Jurnal Bimbingan Konseling, 7.

Febrianti, T., \& Mulawarman, M. (2019). Peningkatan Perilaku Prososial Siswa melalui Konseling Teman Sebaya Berbasis Kecakapan Hidup. Indonesian Journal of Educational Counseling, 3(3), 293-300. https://doi.org/10.30653/001.201933.113

Habsy, B. A., Hidayah, N., Lasan, B. B., Muslihati, \& Fudholi, A. (2019). The Development Model of Semar Counselling to Improve the Self-Esteem of Vocational Students with Psychological Distress. International Journal of Emerging Technologies in Learning, 14(10), 132-149. https://doi.org/10.3991/ijet.v14i10.10221

Kurniawati Husada, A. (2013). Hubungan Pola Asuh Demokratis dan Kecerdasan Emosi dengan Perilaku Prososial pada Remaja. Persona:Jurnal Psikologi Indonesia, 2(3), 266-277. https://doi.org/10.30996/persona.v2i3.160

Kusnadi, Y. (2016). Pengaruh Keterimaan Aplikasi Pendaftaran Online terhadap Jumlah Pendaftar di Sekolah Dasar Negeri Jakarta. Paradigma, XVIII(2), 89-101.

Kusumawati, Y., Astuti, D., Darnoto, S., Wijayanti, A. C., \& Setiyadi, N. A. (2015). Model Pemberdayaan Konseling Peer Education dalam Upaya Membentuk Perilaku Berhenti Merokok pada Mahasiwa. University Research Colloquium, 104125.

Laursen, B. (2005). Dyadic and Group Perspectives on Close Relationships. International Journal of Behavioral Development, 29(2), 97-100. https://doi.org/10.1080/01650250444000450

Megawati, E., \& Herdiyanto, Y. K. (2016). Hubungan antara Perilaku Prososial dengan Psychological Well-Being pada Remaja. Jurnal Psikologi Udayana,3(1). https://doi.org/10.24843/jpu.2016.v03.i01.p13

Muslikah., Hariyadi, S., \& Amin, Z. N. (2016). Pengembangan Model Peer Counseling sebagai Media Pengalaman Praktik Konseling. Indonesian Journal of Guidance and Counseling: Theory and Application, 5(3), 48-52.

Prasetiawan, H. (2015). Konseling Teman Sebaya untuk Mereduksi Kecanduan Game Online. Counsellia: Jurnal Bimbingan Konseling, 6(1), 1-13. 
Rahmi, S., Mappiare-AT, A., \& Muslihati, M. (2017). Karakter Ideal Konselor dalam Budaya Bugis Kajian Hermeneutik Terhadap Teks Pappaseng. Jurnal Pendidikan: Teori, Penelitian, dan Pengembangan, 2(2), $228-237$.

Rozga, M. R., Kerver, J. M., \& Olson, B. H. (2015). Prioritization of Resources for Participants in a Peer Counseling Breastfeeding Support Program. https://doi.org/10.1177/0890334414554420

Santoso, L. S. (2017). Etnografi Warung Kopi: Politik Identitas Cangkrukan di Kota Surabaya dan Sidoarjo. Mozaik Humaniora, 17(1), 113-125. https://doi.org/10.20473/MH.V17I1.6594

Sari, N. P. (2017). Pengembangan Modul Pelatihan Konseling Teman Sebaya untuk Anggota PMR di SMP Negeri 1 Banjarmasin. Proceeding Seminar Dan Lokakarya Nasional Revitalisasi Laboratorium dan Jurnal Ilmiah Dalam Implementasi Kurikulum Bimbingan dan Konseling Berbasis KKNI, 4-6.

Sukarno, T., \& Handarini, D. (2017). Pengembangan Panduan Pelatihan Creative Problem Solving untuk Mencegah Bullying di SMP. Jurnal Kajian Bimbingan dan Konseling, 1(2), 33-39. https://doi.org/10.17977/um001v1i12016p033

Sungkowati, Y. (2019). Arek Culture In Literary Works. Jurnal International Seminar on Languages, Literature, Arts and Education (ISLLAE), 1(1), 165-170. https://doi.org/doi.org/10.21009/ISLLAE.01126

Suwarjo. (2008). Konseling Teman Sebaya (Peer Counseling) untuk Mengembangkan Resiliensi Remaja. Pengembangan Ilmu Pendidikan Fakultas Ilmu Pendidikan Universitas Negeri Yogyakarta, 1-16.

Tikawati, D. (2014). Peningkatan Keterampilam Interpersonal Melalui Permainan pada Siswa Kelas VII B SMP Negeri 15 Yogyakarta (Vol. 2014). https://doi.org/10.1038/132817a0

Turner, R. N., Crisp, R. J., \& Lambert, E. (2007). Imagining Intergroup Contact can Improve Intergroup Attitudes. Group Processes and Intergroup Relations, 10(4), 427-441. https://doi.org/10.1177/1368430207081533

Uke, G. O., Ramli, M., \& Triyono. (2017). Keefektifan Pemodelan Sebaya (Peer Modeling) untuk Mengurangi Prokrastinasi Akademik Siswa SMK. Jurnal Pendidikan: Teori, Penelitian, dan Pengembangan, 2(2), 173-178.

UNESCO. (2001). THe Right To Education Towards Education For All Throughout Life. In International Journal of Educational Development (Vol. 21). https://doi.org/10.1016/s0738-0593(01)00003-7

Yusron, M. Z., Hidayah, N., \& Atmoko, A. (2018). Pengembangan Konseling Person Centered Bermuatan Nilai Budaya Sasak. Jurnal Pendidikan: Teori, Penelitian, dan Pengembangan, 3(11), 1411-1416. https://doi.org/10.17977/JPTPP.V3I11.11775

Zuhara, E. (2015). Efektivitas Tekhnik Sosiodrama untuk Meningkatkan Komunikasi Interpersonal Siswa. Jurnal Ilmiah Edukasi, 1, 80-89. 